\title{
PEMBERDAYAAN REMAJA MASJID DAN PERANNYA DALAM PENDIDIKAN ISLAM
}

\author{
Beny Sintasari \\ STIT Al Urwatul Wutsqo Jombang \\ (sintasari398@gmail.com)
}

\begin{abstract}
:
Youth empowerment and mentoring aims to make them a good young generation; namely adolescents who are righteous, faithful, knowledgeable, skilled and have noble character. To foster Muslim teenagers, it can be done in various approaches, including through the activities of youth mosques. Mosque youth is an organization that accommodates Muslim youth activities in prospering mosques. Mosque youth is an alternative forum for youth development that is good and needed by the people. By being oriented towards mosque, Islamic, scientific, youthful and skill activities, this organization can provide opportunities for its members to develop themselves according to their talents and creativity. Mosque youth have a very important role because mosque youth is an organization that really thinks about the development of Islam. Mosque youth play a role in the spread of Islamic culture. Through mosque youth, we can gradually instill Islamic values in children, so that they can fortify the Muslim generation in every activity.
\end{abstract}

Keyword: empowerment, mosque youth

\section{Pendahuluan}

Secara etimologi pemberdayaan berasal dari kata dasar "daya" yang artinya kekuatan dan kemampuan. Pemberdayaan dapat dimaknai sebagai suatu proses untuk memperoleh daya/kekuatan/kemampuan atau proses pemberian daya/kekuatan/kemampuan dari pihak yang memiliki daya kepada pihak yang kurang atau belum berdaya. Peran pemberdayaan juga menumbuhkembangkan sebuah potensi yang dimiliki pada tiap-tiap individu atau masyarakat. ${ }^{1}$

Pada dasarnya pemberdayaan mengandung unsur pemberian kewenangan dan peningkatan kapasitas masyarakat termasuk masyarakat local. Mengingat dalam setiap perspektif pembangunan masyarakat yang berbeda, pasti

\footnotetext{
1 Sulistiyani, dan Ambar Teguh. Kemitraan dan Model-Model Pemberdayaan. (Yogyakarta: Gava Media, 2004), 77 
menggunakan filosofi, asumsi dan logika berfikir yang berbeda, maka agar implementasi perubahan perspektif cukup efektif dibutuhkan adanya reorientasi. ${ }^{2}$

Pemberdayaan dan pendampingan remaja bertujuan agar mereka menjadi generasi muda yang baik; yaitu remaja yang shalih, beriman, berilmu, berketerampilan dan berakhlak mulia. Untuk membina remaja muslim bisa dilakukan dalam berbagai pendekatan, diantaranya melalui aktivitas remaja masjid. Remaja masjid adalah organisasi yang mewadahi aktivitas remaja muslim dalam memakmurkan masjid. Remaja masjid merupakan salah satu alternatif wadah pembinaan remaja yang baik dan dibutuhkan umat. Dengan berorientasi pada aktivitas kemasjidan, keislaman, keilmuan, keremajaan dan keterampilan, organisasi ini dapat memberikan kesempatan bagi anggotanya mengembangkan diri sesuai bakat dan kreativitas mereka. Remaja masjid memiliki peran yang sangat penting karena remaja masjid merupakan organisasi yang benar-benar memikirkan perkembangan Islam. Remaja masjid memegang peranan dalam penyebaran budaya Islam. Melalui remaja masjid secara bertahap kita dapat menanamkan nilai - nilai Islam pada anak, sehingga dapat membentengi generasi Islam dalam setiap aktivitasnya. Eksistensi remaja masjid dalam pelaksanaan pembinaan kepada anak dapat mengarahkan generasi muda Islam untuk mengenal diri mereka sebagai muslim dan lingkungan dimana mereka berada. Melalui remaja masjid kita bisa memotivasi dan membantu anak sebagai generasi muda Islam untuk menggali potensi serta memotivasi mereka dengan mengadakan kegiatan untuk menampilkan kreatifitas mereka. ${ }^{3}$

Organisasi remaja masjid memerlukan para aktivis yang mumpuni dan profesional. Kehadiran mereka tidak bisa serta merta, tetapi perlu diupayakan secara terencana dan terarah melalui sistem pengkaderan, khususnya melalui pelatihan-pelatihan yang sangat mendukung. Berdasarkan penjelasan diatas, maka diperlukan sebuah pelatihan manajemen dakwah, organisasi dan kepemimpinan bagi remaja masjid, sehingga nantinya para remaja mempunyai sikap yang sigap, tegas dan bertanggung jawab dalam menyelesaikan masalah-masalah yang ada di wilayahnya.

Dalam perspektif Al-Qur'an, signifikansi masjid melakukan pembinaan kepada pemuda didasarkan pada penjelasan al-Qur'an bahwa umat Islam perlu mencontoh generasi Ashab al-Kahfi dalam mempersiapkan generasi muda. Mereka adalah generasi yang memiliki keimanan dan ketaqwaan kepada Allah serta mampu mempertahankan keyakinannya di hadapan penguasa yang ingin

\footnotetext{
2 Soetomo, Pemberdayaan Masyarakat, (Yogyakarta: Pustaka Pelajar, 2015), 96-97.

${ }^{3}$ Dedy Susanto (2013), IAIN Walisongo "Pemberdayaan dan Pendampingan Remaja Masjid Melalui Pelatihan Manajemen Dakwah, Organisasi dan Kepemimpinan".
} 
merusak keimanannya. Selain itu, Al-Qur'an juga mengingatkan kepada umat Islam yang terdapat dalam Q.S. An-Nisa ayat 9 :

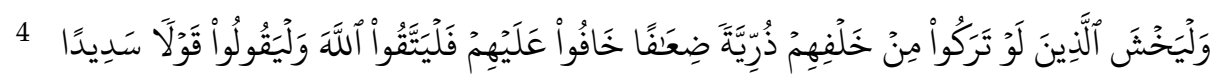

Artinya: Dan hendaklah takut kepada Allah orang-orang yang seandainya meninggalkan dibelakang mereka anak-anak yang lemah, yang mereka khawatir terhadap (kesejahteraan) mereka. Oleh sebab itu hendaklah mereka bertakwa kepada Allah dan hendaklah mereka mengucapkan Perkataan yang benar. ${ }^{5}$

Di dalam hadits juga dijelaskan betapa pemuda ini perlu diberikan bekal pengetahuan dan pengalaman hidup agar pemuda tersebut tumbuh dewasa dan senantiasa mengabdi kepada Allah swt. Pemuda inilah yang nantinya mendapatkan perlindungan di hari kiamat. Usia pemuda adalah gerbang menuju kedewasaan. Jika dia berhasil melalui gerbang ini dengan baik, maka tantangantantangan di masa selanjutnya akan relatif mudah diatasi. Begitupun sebaliknya, bila dia gagal, maka pada tahap perkembangan berikutnya besar kemungkinan akan terjadi masalah pada dirinya.

Pendidikan Islam adalah nama sistem, yaitu sistem pendidikan Islam, yang memiliki komponen-komponen secara keseluruhan mendukung terwujudnya sosok muslim yang diidealkan. Pendidikan Islam adalah pendidikan yang teoriteorinya disusun berdasarkan al Qur'an dan al Hadits. ${ }^{6}$

\section{Konsep Tentang Pemberdayaan}

Unsur utama dari proses pemberdayaan masyarakat adalah pemberian kewenangan dan pengembangan kapasitas masyarakat. Kedua unsur tersebut tidak dapat dipisahkan, oleh karena apabila masyarakat telah memperoleh kewenangan tetapi tidak atau belum mempunyai kapasitas untuk menjalankan kewenangan tersebut maka hasilnya juga tidak optimal.

Untuk memperoleh kewenangan dan kapasitas dalam mengelola pembangunan, masyarakat perlu diberdayakan melalui proses pemberdayaan atau empowerment. Menurut pendapat Korten, memahami power tidak cukup dari dimensi distributive akan tetapi juga dari dimensi generatif. Dalam dimensi distributif, berdasarkan terminology personal, power dapat diartikan sebagai kemampuan seseorang untuk mempengaruhi orang lain. Menurut pendapatnya, sebagai dasar pemahaman pengertian pemberdayaan dalam pembangunan, power dalam dimensi generative justru lebih penting. Suatu kelompok hanya akan

${ }^{4}$ Al-Qur'an surat An-Nisa:9

${ }^{5}$ Departemen Agama RI, Al-Qur'an dan Terjemahnya, (Bandung: Darus Sunnah, 2011),

${ }^{6}$ Muhaimin, Pengembangan Kurikulum Pendidikan Agama Islam, (Jakarta: Rajagrafindo Persada, 2012), 6. 
memperoleh tambahan atau peningkatan power dengan mengurangi power kelompok lain. Kelompok yang bersifat powerless akan memperoleh tambahan power atau empowerment, hanya dengan mengurangi power yang ada pada kelompok powerholders.

Dengan asumsi bahwa masyarakat tidak berdaya karena Negara telah mengambil kewenangan dalam pengambilan keputusan dan pengelolaan pembangunan, maka untuk menambah power bagi masyarakat melalui pemberdayaan harus mengurangi power yang dimiliki oleh Negara. Melalui proses pemberdayaan, Negara harus memberikan sebagian kewenangannya atau sebagian powernya kepada masyarakat.

Dalam kenyataannya, Negara tidak selalu secara sukarela bersedia untuk mengurangi sebagian kewenangannya atau powernya guna diberikan kepada masyarakat. dalam kondisi seperti ini seringkali diperlukan adanya semacam kekuatan penekan. Itulah sebabnya dalam masyarakat kemudian muncul suatu gerakan social yang tujuannya memberikan tekanan agar kepada masyarakat lebih diberikan kewenangan dalam pengambilan keputusan dan atas suatu gerakan yang secara umum menuntut agar masyarakat dapat memperoleh hak-haknya secara proporsional. Untuk keperluan itu pula maka pemberdayaan masyarakat sering dikenal pula institusi yang mengembangkan misi untuk memberikan advokasi kepada masyarakat khususnya masyarakat yang posisinya marginal dan tidak berdaya. ${ }^{7}$

\section{Pendekatan pemberdayaan}

Pemberdayaan masyarakat merupakan suatu proses dimana masyarakat, khususnya mereka yang kurang memiliki akses ke sumber daya pembangunan didorong untuk meningkatkan kemandirian dalam mengembangkan perikehidupan mereka. Pada prinsipnya, masyarakat mengkaji tantangan utama pembangunan mereka, lalu mengajukan kegiatan-kegiatan yang dirancang untuk mengatasi masalah ini. Aktivitas ini kemudian menjadi basis program lokal, regional, bahkan nasional. Target utama pendekatan ini adalah kelompok yang ditermarjinalkan dalam masyarakat, termasuk wanita. Namun demikian, hal ini tidak menafikkan partisipasi dari kelompok lain. Pemberdayaan masyarakat merupakan proses siklus terus-menerus, proses partisipatif dimana anggota masyarakat bekerja sama dalam kelompok formal maupun informal untuk berbagi pengetahuan dan pengalaman serta berusaha mencapai tujuan bersama. Jadi, pemberdayaan masyarakat lebih merupakan suatu proses ketimbang sebuah pendekatan cetak biru.

7 Soetomo, Pemberdayaan Masyarakat, (Yogyakarta: Pustaka Pelajar, 2015), 88. 
Mengembangkan pendekatan pemberdayaan masyarakat akan meningkatkan efektivitas dan efisiensi penggunaan sumber daya pembangunan yang makin langka. Pendekatan ini akan meningkatkan relevansi program pembangunan (pemerintah) terhadap masyarakat local dan meningkatkan kesinambungannya, dengan mendorong rasa memiliki dan tanggung jawab masyarakat. Selain itu, pendekatan ini juga memiliki kontribusi dalam meningkatkan kinerja staf pemerintah dan kepuasan pelanggan atas pelayanan pemerintah.

Hal penting yang perlu dilakukan sebelum memulai penerapan pendekatan ini adalah menciptakan kesadaran dan meyakinkan semua pihak terkait yang terlibat dalam pendekatan pemberdayaan masyarakat atas pentingnya masalah ini. Penyadaran ini khususnya dilakukan untuk mereka yang memegang posisi penting dalam manajemen dan ikut terlibat dalam pengambilan keputusan. Untuk meningkatkan pemahaman dan mengembangkan keahlian lebih jauh, telah dikembangkan sebuah program pelatihan. Program tersebut bisa mencakup pelatihan tentang konsep dasar pemberdayaan, begitu uga keahlian-keahlian spesifik yang dibutuhkan oleh lembaga yang berfungsi memfasilitasinya.

Sebelum memulai implementasi yang sebenarnya, peran dan tanggung jawab semua pihak terkait, alokasi anggaran belanja, dan sistem koordinasi serta komunikasi perlu diperjelas. Secara normal, tim yang memfasilitasi pemberdayaan masyarakat terdiri atas tim multidisipliner. Tim tersebut seyogyanya terdiri atas orang-orang yang memiliki keahlian, latar belakang, dan gender yang berbeda untuk menghindari bias gender dan meningkatkan kepedulian gender.

Mengingat pemberdayaan masyarakat adalah sebuah pendekatan yang relative baru, dibutuhkan perubahan perrilaku dan sikap dari semua pihak terkait yang terlibat. Untuk memulai perubahan ini hendaknya dilakukan dalam skala kecil. Setelah memperoleh pengalaman dan manfaat yang jelas dari pendekatan ini maka penyebarluasannya secara lebih luas bisa dimulai. Hal ini dilakukan dalam organisasi yang sama, juga pada sektor lain. ${ }^{8}$

\section{Remaja Masjid}

Remaja masjid adalah wadah kerja sama yang dilakukan oleh dua orang remaja muslim atau lebih yang memiliki keterkaitan dengan masjid untuk mencapai tujuan bersama. Sebagai generasi muda muslim pewaris masjid, aktivis remaja masjid seharusnya mencerminkan muslim yang memiliki keterikatan dengan tempat beribadah umat Islam tersebut. Siap dan perilakunya Islami, sopan

\footnotetext{
8 Moh Ali Aziz, Rr. Suhartini, A. Halim, Dakwah Pemberdayaan Masyarakat,(Yogyakarta:Pustaka Pesantren, 2005), 135
} 
santun, dan menunjukkan budi pekerti yang mulia (Akhlaqul Karimah). Pemikiran, langkah dan tindak-tanduknya dilandasi oleh nilai-nilai Islam. ${ }^{9}$

Organisasi remaja masjid merupakan suatu organisasi yang dilaksanakan di sekolah sebagai sistem sosial. Pandangan organisasi sebagai suatu sistem sosial dapat ditelusuri dari teori yang dikemukakan oleh Getzels dan Guba mengenai dimensi nomotetik dan ideografik suatu organisasi. Getzels dan Guba melihat kepentingan yang dimiliki oleh personel/pegawai berbeda dengan kepentingan yang ada pada organisasi. Perbedaan inilah yang nantinya akan menghasilkan interaksi antara kebutuhan individu dan organisasi. Hasil interaksi akan terwujud dalam perilaku bentuk pegawai. Dalam hal ini kepemimpinan tidak hanya sebagai suatu kondisi yang disengaja untuk menyelaraskan dua kepentingan yang berbeda, tetapi bagaimana keselarasan ini dapat berjalan dengan baik sehingga pemimpin harus memiliki keterampilan secara khusus dalam hal bagaimana ia memengaruhi perilaku orang lain di dalam organisasi.

Sistem sosial merupakan kegiatan sejumlah orang yang hubungan timbal baliknya kurang lebih bersifat konstan. Sekolah terdiri dari orang-orang yang memiliki hubungan satu sama lain. Setiap orang yang berada di sekolah memiliki peran yang harus dijalankan supaya system interaksi tersebut tetap terjaga. Peran yang dapat diidentifikasi di sekolah adalah guru, siswa, kepala sekolah, staf TU, laboran, pustakawan, penjaga sekolah, satpam sekolah. Dalam hal ini Lawang mengemukakan bahwa :"Setiap sistem sosial selalu mempertahankan batas-batas yang memisahkan dan membedakannya dari lingkungan, serta mempertahankan keseimbangan dari kegiatan-kegiatan yang memungkinkannya terus bertahan dan beroperasi". Karenanya merupakan hal yang benar bahwa system social itu diciptakan, dipertahankan, dan bahkan diubah atau diganti oleh manusia, bukan terjadi secara alamiah. Asumsi ini menunjukkan bahwa sistem sosial organisasi perlu dikaji dan dikendalikan sehingga tujuan organisasi tercapai melalui perantara perilaku pegawai. ${ }^{10}$

Selain itu terdapat nilai-nilai penting untuk mempelajari perilaku organisasi karena nilai meletakkan fondasi untuk memahami sikap dan motivasi serta mempengaruhi persepsi kita. Individu-individu memasuki suatu organisasi dengan gagasan yang di konsepsikan sebelumnya mengenai apa yang "seharusnya" dan "tidak seharusnya". Tentu gagasan-gagasan itu tidak bebas nilai. Bahkan Robbins menambahkan bahwa nilai itu mempengaruhi sikap dan perilaku. ${ }^{11}$

\footnotetext{
9 Muhammad Arifin Ilham \& Muhammad Muslih Aziz, Cinta Masjid Berkah Negeriku, (Jakarta: Cicero Plubishing, 2010), 156.

${ }^{10}$ Cepi Triatna, Perilaku Organisasi Dalam Pendidikan, (Bandung: Remaja Rosdakarya, 2015), 26.

11 S. P. Robbins, Organizational Behaviour,(New Jersey: Prentice Hall, Inc, 1991), 158.
} 
Dalam berorganisasi dibutuhkan adanya strategi pengembangan organisasi. Pengembangan organisasi akan cenderung gagal jika tidak dilakukan dengan menggunakan strategi yang tepat. Strategi yang tepat merupakan suatu kondisi yang memecahkan masalah organisasi. Edward E. Lawler mengungkapkan sebuah model strategi dalam pengembangan organisasi yang dikenal dengan model berlian berikut.

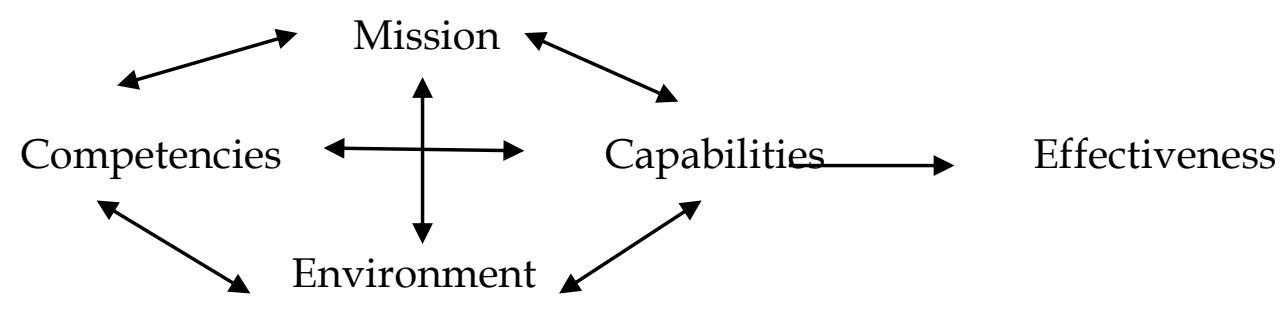

Gambar . Model berlian dari Edward E. Lawler

Lawler mengungkapkan bahwa strategi pengembangan organisasi yang bagus adalah strategi yang dapat menyesuaikan empat poin, yaitu misi organisasi, kompetensi pegawai, kapasitas pegawai, dan lingkungan organisasi. Misi organisasi adalah sesuatu yang harus dilaksanakan oleh organisasi agar tujuan organisasi dapat terlaksana dan tercapai dengan baik. Dengan pernyataan misi tersebut, yang diharapkan seluruh anggota dan pihak yang berkepentingan dapat mengenal organisasi, menentukan peran dan program-programnya serta hasil yang diperoleh dimasa mendatang.

Kompetensi adalah merupakan kinerja tugas rutin yang integratif, yang menggabungkan resources (kemampuan, pengetahuan, asset dan proses, baik yang terlihat maupun yang tidak terlihat) yang menghasilkan posisi yang lebih tinggi dan kompetitif. Kompetensi pegawai bertujuan untuk memastikan dan memelihara kemampuan pegawai sehingga memenuhi kualifikasi yang diprasyaratkan sehungga selaras dengan tujuan organisasi agar dapat tercapai sebagaimana yang direncanakan.

Kapasitas pegawai adalah suatu proses yang dapat meningkatkan kemampuan pegawai, suatu organisasi atau suatu system untuk mencapai tujuantujuan yang dicita-citakan atau sering dikenal dengan system manajemen. Lingkungan organisasi adalah elemen-elemen yang berada di luar organisasi tersebut dan secara potensial mempengaruhi kinerja organisasi. Lingkungan dapat dibagi 2 yaitu : Lingkungan eksternal dan Lingkungan internal.

Lingkungan organisasi sebagai sesuatu yang memberikan energi penyaluran dan penerimaan organisasi yang berada di sekitar organisasi dan memberikan pengaruh pada kelangsungan organisasi tersebut. Menjalankan sebuah organisasi tidaklah mudah, ada beberapa konflik atau masalah yang harus dihadapi dan 
perlu diselesaikan. Pemecahan konflik dalam organisasi akan melibatkan berbagai pihak terkait, bahkan pimpinan terlibat langsung dalam upaya pemecahan masalah. Dalam konteks konflik sebagai bagian untuk mendinamisasi dan meningkatkan kinerja individu atau kelompok, maka penanganan konflik harus didekati dengan berbagai cara yang memunculkan iklim yang sehat. Untuk ada lima pendekatan untuk menangani permasalahan konflik dalam organisasi, yaitu sebagai berikut:

1. Berkompetisi: kedua belah pihak saling bersaing untuk menjadi yang terbaik (kompetisi sehat).

2. Berkolaborasi: pihak yang sedang berkonflik saling bergabung dengan dilandasi keinginan saling memperhatikan untuk memuaskan kedua belah pihak sehingga konflik dapat diperkecil.

3. Menghindar: situasi dimana pihak yang satu menghindari untuk tidak melakukan kontak atau komunikasi dengan pihak yang menjadi lawannya.

4. Mengakomodasi: kegiatan penyelesaian konflik dengan memberikan konflik dengan memberikan kesempatan atau tempat kepada pihak lain untuk mendapatkan apa yang diinginkannya.

5. Berkompromi: situasi dimana setiap pihak yang berkonflik bermusyawarah untuk saling memberikan saran/pendapat mencari solusinatau jalan keluar. ${ }^{12}$

\section{Pembinaan Terhadap Generasi Muda Islam}

Pembinaan terhadap generasi ini memiliki tujuan diantaranya :

1. Mewujudkan generasi Islam yang memiliki pemahaman Islam yang benar.

2. Membekali generasi muda yang berkualitas secara moral, amal, ilmu, dan keahlian.

3. Membangun generasi muda yang memiliki karakteristik Islam yang khas.

4. Menciptakan generasi muda yang berjuang untuk Islam.

5. Membangun generasi muda yang peduli terhadapnya umatnya.

Anak-anak muda perlu diajak untuk melakukan kegiatan yang sifatnya jasadiyah (fisik) dan ruhiyyah (pembinaan mental). Keduanya menjadi unsur terpenting dalam pembinaan. Program jasadiyah bisa dilaksanakan dengan jalan kaki bersama atau lari bersama, naik sepeda bersama, sepak bola bersama, tenis, renang bersama, kemah bersama, atau bela diri, dan lainnya.

Kegiatan yang sifatnya ruhiyyah diantaranya : tadabbur alam, shalat malam bersama, mengunjungi orang sakit (teman atau saudara) bersama, tadarus bersama

${ }^{12}$ Cepi Triatna, Perilaku Organisasi Dalam Pendidikan, 134. 


\section{Beny Sintasari}

Pemberdayaan Remaja Masjid...

(membaca dan menyimak al-Qur'an), bakti sosial untuk orang yang kurang mampu, munajat, dan evaluasi awal tahun dan akhir tahun, dan lainnya. ${ }^{13}$

\section{Beberapa Nasihat Bagi Remaja Masjid}

Mereka berkarya dan berjuang untuk menegakkan kalimat Allah dalam rangka beribadah mencari keridhoan-Nya. Allah SWT menjadi tujuannya dan Rasulullah SAW menjadi teladan sekaligus idolanya. Gerak dan aktivitasnya berada dalam siklus: beriman, berilmu, beramal sholeh dan beramar ma'ruf nahi munkar, menuju kesuksesan dan kebahagiaan didunia dan akhirat.

Beberapa sikap dan perilaku praktis yang perlu diperhatikan aktivis remaja masjid antara lain:

1. Menyadari sebagai pemakmur masjid

2. Mengamalkan adab sopan santun

3. Menjaga pergaulan antara laki-laki dan perempuan

4. Menjaga suara dan pembicaraan

5. Rajin melaksanakan sholat berjama'ah di masjid

6. Mengembangkan kepribadian yang menarik

7. Rajin menuntut ilmu

8. Berusaha terlibat dalam kepengurusan remaja masjid ${ }^{14}$

\section{Tugas Remaja Muslim}

Remaja muslim diciptakan dimuka bumi ini untuk mewujudkan ketaatan dan pengabdian kepada Allah serta untuk menyerahkan diri sepenuhnya terhadap seluruh keputusan-Nya. Hal ini sebagaimana yang dikatakan Allah dalam firmanNya:

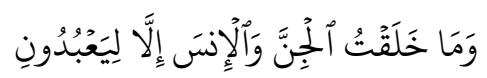

Artinya: dan Aku tidak menciptakan jin dan manusia melainkan supaya mereka menyembahKu. (Q.s Adz-Dzariyat:56) ${ }^{15}$

Kalian diciptakan untuk tetap konsekwen kepada konsepsi Robbani yang suci dari rona-rona kebatilan, baik yang dating dari depan maupun dari belakang. Konsepsi ini bersumber dari Dzat yang Maha bijaksana lagi Maha terpuji. Allah SWT berfirman:

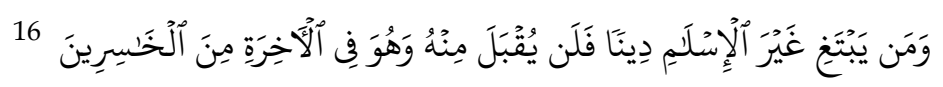

\footnotetext{
${ }^{13}$ Budiman Mustofa, Manajemen Masjid, (Solo: Ziyad Visi Media, 2008), 148.

${ }^{14}$ Muhammad Arifin Ilham \& Muhammad Muslih Aziz, Cinta Masjid Berkah Negeriku, 157.

${ }^{15}$ Departemen Agama RI, Al-Qur'an dan Terjemahnya Special For Women, (Bandung: Sygma, 2005), 523.
} 


\section{Beny Sintasari}

Pemberdayaan Remaja Masjid...

Artinya: barang siapa mencari agama selain agama Islam, maka sekali-kali tidaklah akan diterima (agama itu) daripadanya, dan dia di akhirat termasuk orang-orang yang rugi.(Q.s Al-Imran:85) ${ }^{17}$

Kalian diperintah Allah untuk siap dipimpin dan loyal kepada-Nya, kepada RasulNya dan kepada orang-orang mukmin, sebagaimana firman Allah SWT:

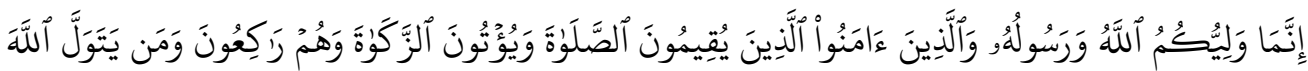

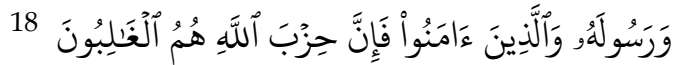

Artinya: sesungguhnya penolong kamu hanyalah Allah, Rasul-Nya, dan orang-orang yang beriman, yang mendirikan sholat dan menunaikan zakat, seraya mereka tunduk (kepada Allah). Dan barang siapa mengambil Allah, Rasul-Nya dan orang-orang yang beriman menjadi penolongnya maka sesungguhnya pengikut (agama) Allah itulah yang pasti menang. (Q.s AlMaidah:55-56) ${ }^{19}$

Misi besar yang Allah berikan kepada remaja muslim adalah memberlakukan hokum-hukumNya diseluruh penjuru dunia dan untuk mengalihkan manusia dari penghambaan terhadap sesamanya. Juga untuk membebaskan umat manusia dari alam yang sempit menuju alam bebas merdeka. ${ }^{20}$ Pembahasan remaja masjid berarti tidak lepas dari pembahasan masjid. Masjid merupakan tempat orang berkumpul dan melakukan shalat secara berjamaah, dengan tujuan meningkatkan solidaritas dan silaturrahmi di kalangan kaum muslimin.

Kehidupan sehari-hari dari umat Islam terkait erat dengan masjid yang didirikan atas dasar iman. Penampilan dan manajemen masjid dapat memberi gambaran tentang hubungan masjid dengan kualitas sumber daya manusia di sekelilingnya. Manajemen masjid harus dilaksanakan sebagai pengamalan dan hubungan manusia dengan Allah SWT. ${ }^{21}$ Kebijakan pemerintah dalam pemberdayaan masjid saat ini diarahkan pada upaya mendorong masyarakat untuk mengoptimalkan pelayanan masjid di bidang sosial-keagamaan, seperti

\footnotetext{
16 Al-Qur'an surat Al-Imran (3:85)

17 Departemen Agama RI, Al-Qur'an dan Terjemahnya Special For Women, (Bandung: Sygma, 2005), 61.

18 Al-Qur'an surat Al-Maidah (5:55-56)

19 Departemen Agama RI, Al-Qur'an dan Terjemahnya Special For Women, (Bandung: Sygma, 2005), 117.

${ }^{20}$ Abdullah Nashih Ulwan, Pesan Untuk Pemuda Islam,(Jakarta: Gema Insani Press, 1996), 11.

${ }^{21}$ M. E Ayub, Muhsin dan Ramlan Marjoned, Manajemen Masjid, (Jakarta: Gema Insani 1996),1.
} 
dalam kegiatan pernikahan dan pembinaan keluarga sakinah, sosialisasi produk halal, sosialisasi zakat dan wakaf, dan lain-lain.

Di samping itu, pemerintah menginginkan masjid memiliki peran nyata dalam meningkatkan penyuluhan dan pendidikan agama pada masyarakat, kemitraan umat, pemberdayaan lembaga keagamaan dan dakwah Islamiyah. Untuk itulah Kementerian Agama melalui Direktorat Urusan Agama Islam dan Pembinaan Syariah pada setiap tahun anggaran memberikan bantuan dana untuk tempat ibadah, khususnya bantuan pembangunan masjid, dan termasuk rehabilitasi pasca bencana dan pengembangan perpustakaan masjid.

Program tersebut dilakukan dalam rangka meningkatkan fungsi dan peran tempat ibadah. Dasar fungsi masjid dalam al-Qur'an ada 4 yaitu: Pertama, masjid tempat untuk melakukan aktifitas yang mengandung ketaatan, kepatuhan dan ketundukan total kepada Allah SWT. Kedua, fungsi peribadatan (ubudiyah) masjid, yakni tumputan masjid yang untuk membangun nilai taqwa. Ketiga, masjid sebagai fungsi etik, moral, dan sosial. Keempat, masjid sebagai tempat keilmuan dan kependidikan. ${ }^{22}$

\section{Kegiatan Positif Remaja Masjid}

Ada beberapa kegiatan positif yang bisa dilakukan oleh remaja Masjid antara lain: Posko Kebanjiran Atau Bencana Alam, Pengajian Intensif, Pengajian Iqra/ AlQur'an, Pesantren Ramadhan/ Kilat, Pemberian Beasiswa, Khitanan Masal, Peringatan Hari Besar Islam, Perprustakaan, Bazar Amal, Kursus; Bahasa, Kaligrafi, Perlombaan-Perlombaan; Nasyid, Qasidah, Penerbitan ${ }^{23}$

Dari beberapa kegiatan-kegiatan remaja masjid yang agamis, secara otomatis akan menciptakan budaya religious di lembaga pendidikan. Budaya religius di lembaga pendidikan adalah upaya terwujudnya nilai-nilai ajaran agama sebagai tradisi dalam berperilaku dan budaya organisasi yang diikuti oleh seluruh warga di lembaga pendidikan tersebut. ${ }^{24}$ Budaya religius yang ada di lembaga pendidikan biasanya bermula dari penciptaan suasana religius yang disertai dengan penanaman nilai-nilai religius secara istiqomah. Kegiatan-kegiatan yang dapat menumbuhkan budaya religius (religious culture) di lingkungan lembaga pendidikan antara lain:

\footnotetext{
22 Moh. Roqib, Menggugat Fungsi Edukasi Masjid, (Yogyakarta: Grafindo Litera Media), 2005, 73.

${ }^{23} \mathrm{http}: / /$ remajabah.blogspot.co.id/2014/12/program-kerja-remaja-masjid-babul_5.html , diakses pada 5 Agustus 2016, pukul 11:54 WIB

${ }^{24}$ Asmaun Sahlan, Mewujudkan Budaya Religius di Sekolah :Upaya Mengembangkan PAI dari Teori ke Aksi, (Malang: UIN Maliki Press, 2010), 77.
} 
1. Melakukan kegiatan rutin, yaitu pengembangan budaya secara religious secara rutin berlangsung pada hari-hari biasa di lembaga pendidikan.

2. Menciptakan lingkungan lembaga pendidikan yang mendukung dan menjadi laboratorium bagi penyampaian pendidikan agama, sehingga lingkungan dan proses kehidupan semacam ini bagi para peserta didik benar-benar bisa memberikan pendidikan tentang caranya belajar beragama.

3. Pendidikan agama tidak hanya disampaikan secara formal oleh guru agama dengan materi pelajaran agama dalam suatu proses pembelajaran, namun dapat pula dilakukan diluar proses pembelajaran dalam kehidupan seharihari.

4. Menciptakan situasi atau keadaan religious. Tujuannya untuk mengenalkan kepada peserta didik tentang pengertian agama dan tata cara pelaksanaan agama tersebut dalam kehidupan sehari-hari.

5. Memberikan kesempatan kepada peserta didik sekolah/madrasah untuk mengekspresikan diri, menumbuhkan bakat, minat dan kreatifitas pendidikan agama dalam keterampilan dan seni, seperti membaca al-Qur'an, adzan, sari tilawah, serta untuk mendorong peserta didik sekolah mencintai kitab suci, dan meningkatkan minat peserta didik untuk membaca, menulis, serta mempelajari isi kandungan al-Qur'an.

6. Menyelanggarakan berbagai macam perlombaan seperti cerdas cermat untuk melatih dan membiasakan keberanian, kecepatan, dan ketepatan menyampaikan pengetahuan dan mempraktekan materi pendidikan agama Islam.

7. Diselenggarakannya aktivitas seni, seperti seni suara, seni music, seni tari, atau seni kriya. Seni menentukan kepekaan peserta didik dalam memberikan ekspresi dan tanggapan dalam kehidupan. Seni memberikan kesempatan kepada peserta didik untuk mengetahui atau menilai kemampuan akademis, social, emosional, budaya moral dan kemampuan pribadinya lainnya untuk pengembangan spiritual rohaninya. ${ }^{25}$

\section{Peran Kegiatan Keagamaan Dalam Meningkatkan Mutu Pendidikan}

Kegiatan yang dilaksanakan remas berpengaruh pada peningkatan mutu pendidikan, karena berperan langsung dalam pengembangan pembelajaran pendidikan agama atau religiusitas. Pendidikan agama atau religiusitas tidak hanya mengarah pada aspek kognitif saja, namun seharusnya mengarah pada praktik dan kegiatan social dalam aktivitas keseharian baik di lembaga pendidikan maupun di luar lembaga pendidikan. Model pembelajaran yang demikianlah yang

25 Muhammad Fathurrohman, Budaya Religius Dalam Peningkatan Mutu Pendidikan, (Yogyakarta: Kalimedia, 2015), 108-112. 
akan membuat peserta didik lebih mampu untuk berpikir dan kreatif sehingga akan melahirkan konklusi yang tidak sama dengan gurunya. Model prmbelajaran yang menggunakan pendekatan konstrukstivistik yang sangat dianjurkan pada dekade akhir-akhir ini untuk menggebrak dan meningkatkan mutu pendidikan nasional. Kegiatan keagamaan dapat meningkatkan daya nalar dan juga hasil belajar. Hal tersebut dikarenakan daya nalar dan hasil belajar akan meningkat jika emosi mengalami ketenangan. Salah satu factor yang mempengaruhi hasil belajar adalah problem pribadi, yaitu emosi. ${ }^{26}$ Dan hal itu bisa ditenangkan dengan budaya religius atau kegiatan keagamaan. Karena menurut penelitian Muhaimin, dalam bukunya, kegiatan keagamaan seperti Khotmil al-Qur'an dan istighotsah dapat menciptakan suasana ketenangan dan kedamaian dikalangan civitas akademika lembaga pendidikan. Maka dari itu, suatu lembaga pendidikan tersebut mengalami ketentraman emosinya, maka secara otomatis semuanya mampu berpikir dengan tenang tersebut mampu menemukan sesuatu yang baru. ${ }^{27}$ Penerapan Motivasi dalam Organisasi

Setiap organisasi dituntut untuk menyusun sebuah kerangka yang tepat bagaimana motivasi itu dapat dilakukan pada setiap individu yang terlibat didalamnya. Motivasi merupakan tugas pimpinan untuk mengimplementasikannya kepada seluruh karyawan. Motivasi dapat membentuk suatu pencapaian tujuan melalui mobilisasi sumber daya manusia antara lain ditentukan oleh ketepatannya dalammenyusun kerangka motivasi tersebut. Dalam perkembangan ilmu dan teknologi pada masa sekarang dimana didalamnya terjadi perubahan dan perkembangan organisasi serta motivasi yang tidak pernah surut. Dengan makin berkembangnya aplikasi komputer, munculah pola hubungan kerja yang bersifat dispersonal dalam organisasi, malah memperbesar kecenderungan untuk melakukan perjumpaan face to face (tatap muka) secara intensif. Dengan demikian, motivasi dapat menyambungkan hubungan batin, emosinal, profesionalitas, dan intelektualitas antara pemimpin dan karyawan dalam sebuah organisasi.

Dari motivasi itulah pegawai dalam organisasi dapat diarahkan untuk menjalankan perannya secara optimal. Motivasi merupakan sebuah metode bagaimana pegawai dalam organisasi dapat ditangani secara tepat untuk mencapai tujuan organisasi. Dalam hal ini kita dapat menyatakan bahwa efektivitas kepemimpinan dalam organisasi antara lain dapat dilihat dari

\footnotetext{
26 Yahya Khan, Pendidikan Karakter Berbasis Potensi Diri: Mendongkrak Kualitas

Pendidikan, (Yogyakarta: Pelangi Publishing, 2010), 12.

27 Muhammad Fathurrohman, Budaya Religius Dalam Peningkatan Mutu Pendidikan, 161-163.
} 


\section{Beny Sintasari}

Pemberdayaan Remaja Masjid...

kemampuan seorang pemimpin dalam memberikan motivasi kepada para pegawainya. ${ }^{28}$

\section{Kesimpulan.}

Kegiatan yang dilaksanakan remas berpengaruh pada peningkatan mutu pendidikan, karena berperan langsung dalam pengembangan pembelajaran pendidikan agama atau religiusitas. Pendidikan agama atau religiusitas tidak hanya mengarah pada aspek kognitif saja, namun seharusnya mengarah pada praktik dan kegiatan social dalam aktivitas keseharian baik di lembaga pendidikan maupun di luar lembaga pendidikan. Model pembelajaran yang demikianlah yang akan membuat peserta didik lebih mampu untuk berpikir dan kreatif sehingga akan melahirkan konklusi yang tidak sama dengan gurunya. Model prmbelajaran yang menggunakan pendekatan konstrukstivistik yang sangat dianjurkan pada dekade akhir-akhir ini untuk menggebrak dan meningkatkan mutu pendidikan nasional.

\section{DAFTAR PUSTAKA}

Ayub, M. E. Muhsin dan Ramlan Marjoned, Manajemen Masjid, Jakarta: Gema Insani 1996

Aziz, Moh Ali Rr. Suhartini, A. Halim, Dakwah Pemberdayaan Masyarakat, Yogyakarta:Pustaka Pesantren, 2005.

Departemen Agama RI, Al-Qur'an dan Terjemahnya Special For Women, Bandung: Sygma, 2005

Departemen Agama RI, Al-Qur'an dan Terjemahnya, (Bandung: Darus Sunnah, 2011),

Fathurrohman, Muhammad Budaya Religius Dalam Peningkatan Mutu Pendidikan, Yogyakarta: Kalimedia, 2015

Fathurrohman, Muhammad. Budaya Religius Dalam Peningkatan Mutu Pendidikan,

http://remajabah.blogspot.co.id/2014/12/program-kerja-remaja-masjid-

babul_5.html

Ilham, Muhammad Arifin \& Muhammad Muslih Aziz, Cinta Masjid Berkah Negeriku, Jakarta: Cicero Plubishing, 2010

Khan, Yahya. Pendidikan Karakter Berbasis Potensi Diri: Mendongkrak Kualitas Pendidikan, Yogyakarta: Pelangi Publishing, 2010

${ }^{28}$ Cepi Triatna, Perilaku Organisasi Dalam Pendidikan, 91-92. 
Muhaimin, Pengembangan Kurikulum Pendidikan Agama Islam, Jakarta: Rajagrafindo Persada, 2012

Mustofa, Budiman. Manajemen Masjid, Solo: Ziyad Visi Media, 2008.

Robbins, S. P. Organizational Behaviour, New Jersey: Prentice Hall, Inc, 1991

Roqib, Moh. Menggugat Fungsi Edukasi Masjid, Yogyakarta: Grafindo Litera Media, 2005,

Sahlan, Asmaun. Mewujudkan Budaya Religius di Sekolah :Upaya Mengembangkan PAI dari Teori ke Aksi, (Malang: UIN Maliki Press, 2010

Soetomo, Pemberdayaan Masyarakat, Yogyakarta: Pustaka Pelajar, 2015.

Sulistiyani dan Ambar Teguh. Kemitraan dan Model-Model Pemberdayaan. Yogyakarta: Gava Media, 2004.

Susanto, Dedy. "Pemberdayaan dan Pendampingan Remaja Masjid Melalui Pelatihan Manajemen Dakwah, Organisasi dan Kepemimpinan". IAIN Walisongo, 2013

Triatna, Cepi. Perilaku Organisasi Dalam Pendidikan, Bandung: Remaja Rosdakarya, 2015.

Ulwan, Abdullah Nashih Pesan Untuk Pemuda Islam, Jakarta: Gema Insani Press, 1996 